\title{
Patterns of paediatric emergency presentations to a tertiary referral centre in the Northern Territory
}

Running Title: Paediatric Emergency Presentations NT

\author{
Authors \\ Davina Buntsma MBBS BMedSc DCH $(1,2)$ \\ Anna Lithgow MBBS MPHTM FRACP \\ Evan O'Neill MBBS BMedSc (1) \\ Didier Palmer MB BCh FRCP FRCS FRCEM FACEM (3) \\ Peter Morris MBBS RACP PHD (4) \\ Jason Acworth MBBS FRACP (5) \\ Franz E Babl MBBS FRACP $(2,7)$
}

1. Department of Emergency Medicine, The Children's Hospital at Westmead, Sydney, Australia

2. Murdoch Children's Research Institute, Royal Children's Hospital, Melbourne, Victoria, Australia

3. The Department of Emergency Medicine, The Royal Darwin Hospital, Darwin, Northern Territory

This is the author manuscript accepted for publication and has undergone full peer review but has not been through the copyediting, typesetting, pagination and proofreading process, which may lead to differences between this version and the Version of Record. Please cite this article as doi: 10.1111/1742-6723.12853

This article is protected by copyright. All rights reserved. 
4. Menzies School of Health Research Institute, Darwin, Northern Territory, Australia

5. Emergency Department, Lady Cilento Children's Hospital, Brisbane, Queensland

6. Faculty of Medicine, University of Queensland, Brisbane, Queensland

7. Department of Emergency Medicine, Royal Children's Hospital, Melbourne, Victoria

\section{Corresponding author:}

Dr Anna Lithgow

Department of Paediatrics

The Royal Darwin Hospital

PO Box 41326, Casuarina

NT, 0810

annalithgow@gmail.com

$+61416192626$

\section{Co-authors:}

Dr Davina Buntsma

Department of Emergency Medicine

The Children's Hospital at Westmead

Westmead, NSW 
Dr Evan O’Neill

Department of Emergency Medicine

The Children's Hospital at Westmead

Westmead, NSW

Dr Didier Palmer

Department of Emergency Medicine

The Royal Darwin Hospital

TIWI, NT, 0810

Professor Peter Morris

Department of Paediatrics

The Royal Darwin Hospital

TIWI, NT, 0810

Dr Jason Acworth

Faculty of Medicine

The University of Queensland

Brisbane, QLD 
Associate Professor Franz Babl

Department of Emergency Medicine

The Royal Children's Hospital

Melbourne, Victoria

Word Count: 2163

This article is protected by copyright. All rights reserved. 
Patterns of paediatric emergency presentations to a tertiary referral centre in the Northern Territory

\section{ORIGINAL ARTICLE}

\section{Authors}

Davina Buntsma MBBS BMedSc DCH ${ }^{1,2}$

Anna Lithgow MBBS MPHTM FRACP ${ }^{3}$

Evan O'Neill MBBS BMedSc ${ }^{1}$

Didier Palmer MB BCh FRCP FRCS FRCEM FACEM ${ }^{3}$

Peter Morris MBBS RACP PHD ${ }^{4}$

Jason Acworth MBBS FRACP ${ }^{5,6}$

Franz E Babl MBBS FRACP ${ }^{2,7}$

\section{Affiliations}

for the Paediatric Research in Emergency Departments International

Collaborative (PREDICT)

${ }^{1}$ Department of Emergency Medicine, The Children's Hospital at Westmead, Sydney, Australia

${ }^{2}$ Murdoch Children's Research Institute, Royal Children's Hospital, Melbourne, Victoria, Australia

${ }^{3}$ The Department of Emergency Medicine, The Royal Darwin Hospital, Darwin, Northern Territory

${ }^{4}$ Menzies School of Health Research Institute, Darwin, Northern Territory, Australia 
${ }^{5}$ Emergency Department, Lady Cilento Children's Hospital, Brisbane, Queensland

${ }^{6}$ Faculty of Medicine, University of Queensland, Brisbane, Queensland

${ }^{7}$ Department of Emergency Medicine, Royal Children's Hospital, Melbourne, Victoria 


\begin{abstract}
Objective: To describe epidemiological data concerning paediatric attendances at the emergency department (ED) of Royal Darwin Hospital $(\mathrm{RDH})$
\end{abstract}

Methods: We conducted a retrospective cohort study of paediatric emergency visits to RDH ED for the years 2004 and 2013. Epidemiological data, including demographics, admission rates and diagnostic grouping, were analysed using descriptive and comparative statistical methods. We compared 2004 data with findings from a baseline epidemiological study by the Paediatric Research in Emergency Departments International Collaborative (PREDICT) conducted in the same year ${ }^{1}$.

Results: A total of 12745 and 15378 paediatric presentations (age 0 to 18 years) to RDH ED were analysed for the years 2004 and 2013. In 2004 , the mean age of children presenting to RDH was 7.1 years and $44 \%$ were male. Indigenous patients accounted for $31.2 \%$ of presentations at RDH and were significantly more likely to be admitted than non-indigenous patients (31.6\% vs $12.8 \%$, OR $3.24,95 \% \mathrm{Cl} 2.95-3.55)$. Children $<5$ years old accounted for the highest number of presentations (45.2\%) and admissions $(51.2 \%)$ and there was a high proportion of adolescent presentations (18\%). Similar to the PREDICT study, viral infectious conditions (bronchiolitis, gastroenteritis, upper respiratory tract infections) were the most common cause for presentations. Key differences included a higher proportion of 
patients presenting with cellulitis and head injury at RDH and an increasing proportion of adolescent psychiatric presentations at RDH from 2004 to 2013.

\section{Conclusion}

This study provides important information regarding paediatric presentations to a major referral hospital in the Northern Territory. Overall there was a disproportionate rate of presentation and admission amongst Indigenous children. Other key findings were higher proportions of cellulitis, head injury and adolescent presentations. These findings can assist in service planning and in directing future research specific to children in the Northern Territory.

\section{Background/Introduction:}

The Royal Darwin Hospital $(\mathrm{RDH})$ is the largest teaching hospital in the Northern Territory.The RDH Department of Emergency Medicine has an annual census of 68,000 patients, $23 \%$ of these attendances are children. Indigenous Australians represent a large proportion of presentations and the burden and spectrum of disease is very different to that seen elsewhere with high rates of trauma, sepsis, severe gastroenteritis, respiratory illness, poststreptococcal glomerulonephritis and acute rheumatic fever. ${ }^{2-7}$ It is likely that the patterns of paediatric emergency presentations in the Northern Territory differ to the rest of Australia, however this data has not been previously described.

Comprehensive data on patterns of paediatric attendances to Emergency 
Departments (EDs) in Australia was published by the Paediatric Research in Emergency Departments International Collaborative (PREDICT) in 2009¹.

PREDICT is a network of all tertiary paediatric emergency centres and several larger mixed EDs in Australia and New Zealand that was established in 2004 to conduct multicentre research on topics related to the emergency care of children and adolescents. ${ }^{8}$ It was established to overcome a number of obstacles to research on paediatric emergency topics and facilitate better use of the vast amounts of data already available for analysis. The report published investigated at key epidemiological data from 2004 from each member site and included all states in Australia except the Northern Territory and Tasmania.

In the present study, we set out to provide epidemiological data about childhood illness and injuries presenting to the largest ED in the Northern Territory. Data was collected in 2014 . The primary aim was to compare data on ED presentations to RDH with PREDICT in 2004 and then to compare data on ED presentations to RDH in 2004 with data from 2013. This should add to the existing knowledge on paediatric emergency presentations in Australia and New Zealand and inform local priorities in service delivery, education and research.

\section{Methods:}

Our study design was based on the PREDICT epidemiological study and we retrospectively identified all children aged 0-18 years attending the Royal 
Darwin Hospital ED between $1^{\text {st }}$ January 2004 and 31st December 2004 and $1^{\text {st }}$ January 2013 and $31^{\text {st }}$ December 2013. Data was obtained from the ED's existing electronic patient information systems. Diagnoses were based on the International Classification of Diseases $10^{\text {th }}$ revision. $^{9}$

Data collected included:

- Total number of paediatric patient presentations

- Number of presentations by age group, gender, ethnicity, triage category, time of day and month of year

- Number of admissions by age group, gender, ethnicity and month of year

- Mean and median age of patients

- Mode of arrival and disposition

- Most common diagnoses (total and by age group)

We compared RDH 2004 data with data from the PREDICT study in 2004 and subsequently compared RDH 2004 data with RDH 2013 data. The Human Ethic Research Committee of the Northern Territory Department of Health and Menzies School of Health Research approved this project.

\section{Statistical Methods}

Analyses were performed using Microsoft Excel. Percentages were calculated and compared for individual conditions. We considered percentage differences of $>5 \%$ to have the potential to influence practice and differences 
of $>20 \%$ to be highly important. For dichotomous variables, odds ratios (OR) and $95 \%$ confidence intervals $(95 \% \mathrm{Cl})$ were calculated.

\section{Results}

There were a total of 12745 and 15378 paediatric presentations (age 0 to 18 years) to RDH ED for the years 2004 and 2013 respectively. Key epidemiological variables are summarised in Table 1 which includes comparison to 2004 data from the PREDICT study.

When comparing RDH data from 2004 with PREDICT data, the mean age of children at $\mathrm{RDH}$ was 7.1 years and 4.6 years respectively. At $\mathrm{RDH}, 56.0 \%$ were female compared to $44.9 \%$ in PREDICT (OR 1.25, 95\% Cl 1.21-1.28). $45.2 \%$ of presentations at RDH were for children under 5 years of age compared to $59.7 \%$ in PREDICT (OR 0.76, 95\% CI 0.73-0.78), with children in the first year of life responsible for a disproportionately high number of presentations and admissions in both groups. At $\mathrm{RDH}$ there was a higher proportion of adolescent presentations (15-18 years) accounting for $18 \%$ of paediatric ED visits to RDH in 2004 compared to $4.0 \%$ in the PREDICT group (OR 4.48, 95\% Cl 4.17-4.70).

Darwin saw a more uniform number of presentations throughout the year, without the winter peak seen in the PREDICT group. There was a reduction in the number of presentations to RDH in January and July correlating with school holidays (Figure 3). As in PREDICT, a large proportion of presentations occurred between midday and midnight. 
Indigenous patients accounted for $31.2 \%$ of presentations at RDH in 2004 compared to only $2.13 \%$ in PREDICT. Indigenous patients were significantly more likely to be admitted, with $31.6 \%$ Indigenous compared to $12.8 \%$ of nonIndigenous patients admitted in 2004 (OR 3.24, 95\% Cl 2.95-3.55). This compares to an odds ratio of $1.25(95 \% \mathrm{Cl} 1.18-1.31)$ for Indigenous as compared with non-Indigenous subgroups at Australian sites in the PREDICT study.

There was a trend at $\mathrm{RDH}$ for higher acuity patients with $36.8 \%$ of patients being ATS category 1-3 in 2004 compared to $32.4 \%$ in PREDICT (OR 1.06 $95 \% \mathrm{Cl} 1.02-1.10)$. There was a significantly smaller proportion of ATS category 5 presentations at RDH compared to PREDICT (2.8\% vs $15.4 \%$; OR $0.16,95 \% \mathrm{Cl} 0.14-0.18)$

With the exception of infants, where admission rates were higher at $\mathrm{RDH}$, (31.7\% vs $24.3 \%)$ admission rates for other age groups were lower at RDH with the greatest difference in the older adolescents where the admission rate was $15.2 \%$ at RDH compared to $29.6 \%$ in PREDICT (Fig 2). In both groups, the majority of patients were discharged and deaths were rare.

When comparing RDH 2004 data with 2013, overall, the key epidemiological variables were similar. One important difference was a trend for increasing acuity of patients with a significant increase in the proportion of ATS category 2 presentations from $2.4 \%$ to $10.6 \%$ (OR $4.45,95 \% \mathrm{Cl} 3.93-5.04)$. This may 
reflect improved adherence to protocols mandating higher ATS category for neonates and trauma calls.

The ten most frequent diagnoses on presentation to $\mathrm{RDH}$ and in the PREDICT group are presented in Table 2, and the most frequent diagnoses on presentation for each age group are presented in Table 3. The ten most common presentations for the Indigenous sub-group are presented in Table 4.

\section{DISCUSSION}

This is the first study to describe paediatric emergency presentations to a major referral hospital in the Northern Territory and provides important epidemiological data to add to the existing knowledge of paediatric ED presentations in other states of Australia and New Zealand.

As in the PREDICT study, there were high numbers of presentations in the infant and pre-school age groups, and many children presented with infectious diseases (mostly viral) and respiratory conditions. Gastroenteritis remained the top presenting diagnosis to RDH in both 2004 and 2013, similar to the PREDICT study. The overall proportion of presentations reduced from $6.9 \%$ to $5.3 \%(\mathrm{OR} 0.76,95 \% \mathrm{Cl} 0.69-0.84)$, likely correlating with the introduction of the rotavirus vaccine in $2007 .^{10}$

In our study, Indigenous patients accounted for a disproportionately large number of presentations (30\%) and were significantly more likely to be 
admitted than non-Indigenous patients (OR 3.24, 95\% Cl 2.95-3.55).

Indigenous children in The Northern Territory carry a very high burden of disease due to both respiratory tract infections and skin infections ${ }^{11,12}$ and are over-represented given that the Aboriginal and Torres Strait islander people make up only $9.2 \%$ of the greater Darwin region and $26.8 \%$ of the total Northern Territory population. ${ }^{13}$

Cellulitis was a common presentation to RDH ED and disproportionately affected indigenous patients. It did not feature in PREDICT's top ten but was the $2^{\text {nd }}$ most common reason for presenting to hospital for Indigenous patients in 2013 in Darwin. This correlates with data from remote Northern Territory communities where a high burden of skin infections was identified commencing within the first few months of life with $84 \%$ of children presenting with scabies or skin sores before 12 months of age. ${ }^{14,}$ The high prevalence of skin infection is testament to the poor environmental conditions ${ }^{15}$ and household overcrowding in indigenous communities. ${ }^{16}$ Bacterial skin infection, in particular with Group A streptococcal infections contribute to the excess burden of ill health in Indigenous Australians and result in serious sequelae including acute post-streptococcal glomerulonephritis and acute rheumatic fever (ARF). ${ }^{17}$ The incidence of ARF in Australia has risen between 2004 and 2010 from 555 to 647 per 100,000 population, amongst the highest rates worldwide ${ }^{18}$ and mortality rates from rheumatic heart disease in Indigenous Australians are the highest reported in the world. ${ }^{19}$ 
In keeping with current literature, bronchiolitis was also over-represented by Indigenous patients who made up $45.0 \%$ of all cases in 2013 (OR 1.99, 95\% $\mathrm{Cl} 1.59-2.48) .{ }^{5}$ Indigenous children have more frequent respiratory tract infections that are more severe, and associated with the development of chronic suppurative lung disease ${ }^{20}$ Socio-economic risk factors have shown to account for the high rates of both acute and chronic respiratory tract infections in Indigenous children ${ }^{21}, 22$ and are likely to contribute to the high rates of bronchiolitis seen in our population.

Compared to PREDICT, a large proportion of RDH ED patients were adolescents with the 15-18 year age group showing the highest growth rate between 2004 and 2013 (3.3\% per annum). The higher rate of adolescent presentations can likely be explained by RDH being a mixed ED which sees paediatric patients up to 18 years of age, compared to tertiary paediatric hospitals in the PREDICT study that saw patients up to 15 or 16 years of age. The higher admission rate of adolescents in the PREDICT group is likely to reflect referral patterns where older adolescents with complex medical conditions, more frequently needing admission, present to tertiary paediatric centres rather than local adult or mixed EDs. ${ }^{23}$ Similar to the PREDICT group and recent published data from NSW, abdominal pain was the most common reason for presentation to ED for older adolescents in both 2004 and 2013. ${ }^{23}$

In PREDICT, toxic effect of substance (including alcohol) and psychiatric or behavioural problems were the $2^{\text {nd }}$ and $3^{\text {rd }}$ most common reason for 
presentation to emergency in the 15-18 year population. This was not seen in our top 5 diagnoses in 2004 but we saw a significant increase in numbers of psychiatric presentations in 2013 when it was the $2^{\text {nd }}$ most common presentation to ED in the 15-18 year age group. Adolescents with behavioural and psychiatric presentations represent some of the most challenging clinical situations in the Emergency setting with long stays, high admission rates, and recurrent presentations. ${ }^{24,}{ }^{25}$ This trend in adolescent psychiatric presentations in Darwin is particularly concerning given the limited adolescent health services in the top end and the known high rates of psychological illness amongst Indigenous young people. ${ }^{10,26}$

The proportion of children presenting with trauma was higher at $\mathrm{RDH}$ compared to the PREDICT study and increased from 2004 to 2013. When looking at data for head injury, the incidence rate was 2110 per 100000 children attending the ED at RDH in 2004. This is comparable to incidence rates published from The Royal Children's Hospital in Melbourne in 2004. ${ }^{27}$ In 2013 however, we saw the incidence rate of head injury increase by $53 \%$ to 3232 per 100000 children attending the ED (OR $1.54,95 \% \mathrm{Cl} 1.33-1.80)$. When using population data for the Greater Darwin region ${ }^{13}$, the incidence rate of head injury in children $0-18$ in 2013 is 1641 per 100000 which is higher than incidence rates published globally and more than double the incidence rate per population of patients with head injury presenting to Victorian EDs. ${ }^{28,29}$ 
It is well documented that injury is a significant health issue for Aboriginal and Torres Strait Islander people with rates of injury for specific causes many times that of other Australians. ${ }^{30}$ Interestingly, in our population, for the most common injuries specified in our data there were not significant differences between indigenous and non-indigenous cohorts. The increasing rates of trauma, affecting all children, in the Darwin region is of major public health concern. There may be a number of contributing factors such as socioeconomic disadvantage, low levels of parental education, inadequate caregiver supervision of children, poor adherence to child safety laws mandating child car restraints and bike helmets and increased alcohol related violence affecting children. Further research into parental, family and community factors relating to injury is required to guide childhood injury prevention strategies. $^{31}$

\section{Limitations}

Our study was limited by its retrospective design and small sample size compared to the larger original PREDICT study. The data was obtained from the ED's electronic database, which relies on discharge diagnoses inputted by doctors.

\section{Conclusion}

This study provides important information regarding paediatric presentations to a major referral hospital in the Northern Territory. Overall there was a disproportionate rate of presentation and admission amongst Indigenous children. Other key findings were higher rates of cellulitis and adolescent 
presentations. The increasing rates of trauma, particularly head injury is of major concern requiring further evaluation and community attention. These findings can assist in developing services and directing future research specific to children in the Northern Territory.

\section{References}

1. Acworth J, Babl F, Borland M et al. Patterns of Presentation to the Australian and New Zealand Paediatric Emergency Research Network, Emergency Medicine Australasia, (2009) 21 (1), 59-66

2. Gowing $\mathrm{CJ}$, McDermott $\mathrm{K}$ et al.Ten years of trauma in the 'top end' of the Northern Territory, Australia: A retrospective analysis. International Emergency Nursing. 23 (2015) 17-21.

3. Davis JS, Cheng AC, McMillan M et al. Sepsis in the tropical Top End of Australia's Northern Territory: disease burden and impact on Indigenous Australians. Med J Aust. 2011 May 16; 194(10): 519-524.

4. Schultz R. Rotavirus gastroenteritis in the Northern Territory, 19952004. Med J Aust. 2006 Oct 2; 185(7): 354-356.

5. O'Grady KA, Torzillo PJ, Chang AB. Hospitalisation of Indigenous children in the Northern Territory for lower respiratory illness in first year of life. The Med J of Aust. 2010; 192: 586-590.

6. Marshall CS, Cheng AC, Markey PG et al. Acute post- streptococcal glomerulonephritis in the Northern territory of Australia: a review of 16 years data and comparison with the literature. The American Journal of Tropical Medicine and Hygiene 2011; 85: 703-710.

7. Carapetis JR, Wolff DR, Currie BJ. Acute rheumatic fever and 
rheumatic heart disease in the top end of Australia's Northern Territory. MedJ of Aust. 1996; 164: 146-149.

8. Babl F, Borland M, Ngo P et al. Paediatric Research in Emergency Departments international Collaborative (PREDICT): first steps towards the development of an Australian and New Zealand research network. Emerg. Med. Australas. 2006; 18: 143

9. International Statistical Classification of Diseases and Related Health Problems. 10 ${ }^{\text {th }}$ revision. Volume 2. World Health Organisation, 2011.

10. Dey A, Wang H. Changes in hospitalisations for acute gastroenteritis in Australia after the national rotavirus vaccination program. MedJ of Aust. 2012 Oct 15; 197(8): 453-457.

11. Australian Institute of Health and Welfare. The Health and Welfare of Australia's Aboriginal and Torres Strait Islander People 2015 report. http://www.aihw.gov.au/WorkArea/DownloadAsset.aspx?id=601295512 81. Accessed 3/10/16

12. Clucas DB, Carvilee KS, Connors $C$ et al. Disease burden and healthcare clinic attendances for young children in remote Aboriginal communities of northern Australia. Bulletin of the World Health Organization, 2008; 86 (4) 241-320

13. Australian Bureau of Statistics Census of Population and Housing 2011

14. Kears T, Clucas D, Connors C, Currie BJ, Carapetis JR, Andrews RM. Clinic Attendances during the First 12 Months of Life for Aboriginal Children in Five Remote Communities of Northern Australia. PLoS One. $2013 ; 8(3)$

15. Steer AC, Carapetis JR, Nolan TM, et al. Systematic review of 
rheumatic heart disease prevalence in children in developing countries: the role of environmental factors. $J$ Paediatr Child Health 2002; 38:229234

16. Bowen AC, Tong SY, Andrews RM, et al. Short-course oral cotrimoxazole versus intramuscular benzathine benzylpenicillin for impetigo in a highly endemic region: an open-labeled, randomized, controlled, non-inferiority trial. Lancet 2014; 384;2132-2140

17. May PJ, Bowen AC, Carapetis JR. The inequitable burden of group $A$ streptococcal diseases in Indigenous Australina. Med J Aust 2016;205 (50 201-203el

18. Rheumatic heart disease and acute rheumatic fever in Australia: 19962012, Australian Government, Australian Institute of Health and Welfare, Published March 2013, Available online http://www.aihw.gov.au/publication-detail/?id=60129542750, accessed $12 / 10 / 16$

19. Jackson SJ, Steer AC, Campbell H. Systematic review: estimation of global burden of non-suppurative sequelae of upper respiratory tract infection: rheumatic fever and post-streptococcal glomerulonephritis. Trop Med Int Health 2011; 16:2-11

20. Chang $A B$, Brown $N$, Toombs $M$ et al. Lung disease in indigenous children. Paediatric Respiratory Reviews; 15 (4): 325-332

21. Singleton RJ, Valery PC, Morris P et al. Indigenous Children From Three Countries With Non-Cystic Fibrosis Chronic Suppurative Lung Disease/Bronchiectasis. Pediatric Pulmonology 49:189-200 (2014)

22. Reeve CA, Whitehall JS, Buettner PG, et al. Predicting respiratory 
syncytial virus hospitalisation in Australian children. J Paediatr Child Health 2006;42: 248-52.

23. Batra S, Yu Ching E, Foo F et al. Older adolescent presentations to a children's hospital emergency department. Emergency Medicine Australasia (2016) 28, 419-424

24. Steward C, Spicer M, Babl F. Caring for adolescents with mental health problems: challenges in the emergency department. J Paediatr Child Health. 42 (2006) 726-730.

25. Chiristodulu K, Lichenstein R, Wesist MD et al. Psychiatric emergencies in children. Pediatr. Emerg. Care 2002; 18: 268-70

26. Zubrick SR, D'Antoine H. The Mental health of Australian Aboriginal children and adolescents: current status and future prospects. In Hiram E. Fitzgerald Kaija Puura(Ed.), International perspectives on children and mental health. Santa Barbara: Praeger Publishers. 2011.

27. Crowe L,Babl F et al. The epidemiology of paediatric head injuries: data from a referral centre in Victoria, Australia. J. Paediatr Child Health. 2009 Jun;45(6):346-50

28. Mitra, Biswadev, Cameron P, Butt, W. Population-based study of paediatric head injury, Journal of Paediatrics and Child Health 45 (2009) 346-350

29. Michael C. Dewan, Nishit Mummareddy, John C et al. Epidemiology of Global Pediatric Traumatic Brain Injury: Qualitative Review. World Neurosurgery 91:497-509, July 2016

30. Australian Instititue of Health and Welfare. Hospitalised injuries in Aboriginal and Torres Strait Islander children and young people 2011- 
13.

http://www.aihw.gov.au/WorkArea/DownloadAsset.aspx?id=601295546 31. Accessed 4/10/16

31. Robinson G, Moss B, Leckning B. Prevention of unintentional injury in childhood: A selective review of the evidence on unintentional injury, parental supervision and prevention. Office of the Children's Commissioner, 2016.

http://www.childrenscommissioner.nt.gov.au/pdfs/other reports/2016$\underline{03-}$

22\%20ltem $\% 208.13 \% 20$ Unintentional\%20injury\%20FINAL $\% 20010320$ 16.pdf. Accessed 11/4/17

This article is protected by copyright. All rights reserved. 


\section{Tables and figures:}

Table 1: Key epidemiological variables. PREDICT 2004, RDH 2004, 2013.

\begin{tabular}{|c|c|c|c|}
\hline & $\begin{array}{l}\text { PREDICT } 2004 \\
\text { Number of } \\
\text { Presentations, } \\
\text { Proportion (\%) }\end{array}$ & $\begin{array}{l}\text { RDH ED } 2004 \\
\text { Number of } \\
\text { Presentations, } \\
\text { Proportion (\%) }\end{array}$ & $\begin{array}{l}\text { RDH ED } 2013 \\
\text { Number of } \\
\text { Presentations, } \\
\text { Proportion (\%) }\end{array}$ \\
\hline \multicolumn{4}{|l|}{ Age } \\
\hline$<1$ year & $65112(18.5 \%)$ & $1610(12.6 \%)$ & $1976(12.8 \%)$ \\
\hline $1-4$ years & $144916(41.2 \%)$ & $4157(32.6 \%)$ & $4791(31.2 \%)$ \\
\hline $5-9$ years & $72845(20.7 \%)$ & $2595(20.4 \%)$ & $2861(18.6 \%)$ \\
\hline $10-14$ years & $54272(15.4 \%)$ & $2089(16.4 \%)$ & $2726(17.7 \%)$ \\
\hline $15-18$ years & $14121(4.0 \%)$ & $2294(18.0 \%)$ & $3024(19.7 \%)$ \\
\hline Not stated & $174(0.05 \%)$ & 0 & 0 \\
\hline TOTAL & $351440(100 \%)$ & $12745(100 \%)$ & $15378(100 \%)$ \\
\hline \multicolumn{4}{|l|}{ Gender } \\
\hline Male & $193643(55.1 \%)$ & $5614(44.0 \%)$ & $6959(45.3 \%)$ \\
\hline Female & $157797(44.9 \%)$ & $7131(56.0 \%)$ & $8419(54.7 \%)$ \\
\hline \multicolumn{4}{|l|}{ Ethnicity } \\
\hline $\begin{array}{l}\text { Aboriginal } \\
\text { (Australian sites) }\end{array}$ & $7495(2.13 \%)$ & $3977(31.2 \%)$ & $4477(29.15)$ \\
\hline Maori (NZ sites) & $7758(15.8 \%)$ & N/A & $\mathrm{N} / \mathrm{A}$ \\
\hline Pacific (NZ sites) & $13979(28.5 \%)$ & N/A & $\mathrm{N} / \mathrm{A}$ \\
\hline \multicolumn{4}{|c|}{ Triage Category (ATS) } \\
\hline Category 1 & $2098(0.6 \%)$ & $183(1.4 \%)$ & $138(0.9 \%)$ \\
\hline Category 2 & $15581(4.4 \%)$ & 302 (2.4\%) & $1623(10.6 \%)$ \\
\hline
\end{tabular}

This article is protected by copyright. All rights reserved. 


\begin{tabular}{|c|c|c|c|}
\hline Category 3 & $96105(27.3 \%)$ & $3811(29.9 \%)$ & $4761(31.0 \%)$ \\
\hline Category 4 & $182506(51.9 \%)$ & $8087(63.5 \%)$ & $8567(55.7 \%)$ \\
\hline Category 5 & $54055(15.4 \%)$ & $361(2.8 \%)$ & $289(1.9 \%)$ \\
\hline Not stated & $1095(0.3 \%)$ & $1(0.01 \%)$ & 0 \\
\hline \multicolumn{4}{|l|}{ Method of Arrival } \\
\hline Own transport & $316253(90.0 \%)$ & $10334(81.1 \%)$ & $12724(82.7 \%)$ \\
\hline Road ambulance & $30845(8.8 \%)$ & $1001(7.9 \%)$ & $1781(11.6 \%)$ \\
\hline Air ambulance & $1009(0.3 \%)$ & $352(2.8 \%)$ & $492(3.2 \%)$ \\
\hline Other & $318(0.1 \%)$ & $91(0.71 \%)$ & $380(2.5 \%)$ \\
\hline Not stated & $3015(0.9 \%)$ & $967(7.6 \%)$ & $1(0.01 \%)$ \\
\hline \multicolumn{4}{|l|}{ Disposition } \\
\hline Discharged & $251829(71.7 \%)$ & $9562(75.0 \%)$ & $11416(74.2 \%)$ \\
\hline Admitted/transferred & $84463(24.0 \%)$ & $2376(18.6 \%)$ & $3093(20.1 \%)$ \\
\hline $\begin{array}{l}\text { Did not wait to be } \\
\text { seen (DNW) }\end{array}$ & $10129(2.9 \%)$ & $748(5.9 \%)$ & $808(5.3 \%)$ \\
\hline $\begin{array}{l}\text { Left without } \\
\text { treatment (against } \\
\text { medical advice) }\end{array}$ & $4629(1.3 \%)$ & $55(0.4 \%)$ & $59(0.38 \%)$ \\
\hline Died & $65(0.02 \%)$ & $4(0.04 \%)$ & $2(0.01 \%)$ \\
\hline Other & $325(0.1 \%)$ & 0 & 0 \\
\hline
\end{tabular}

This article is protected by copyright. All rights reserved. 


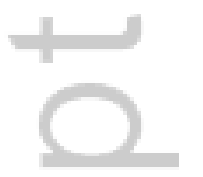




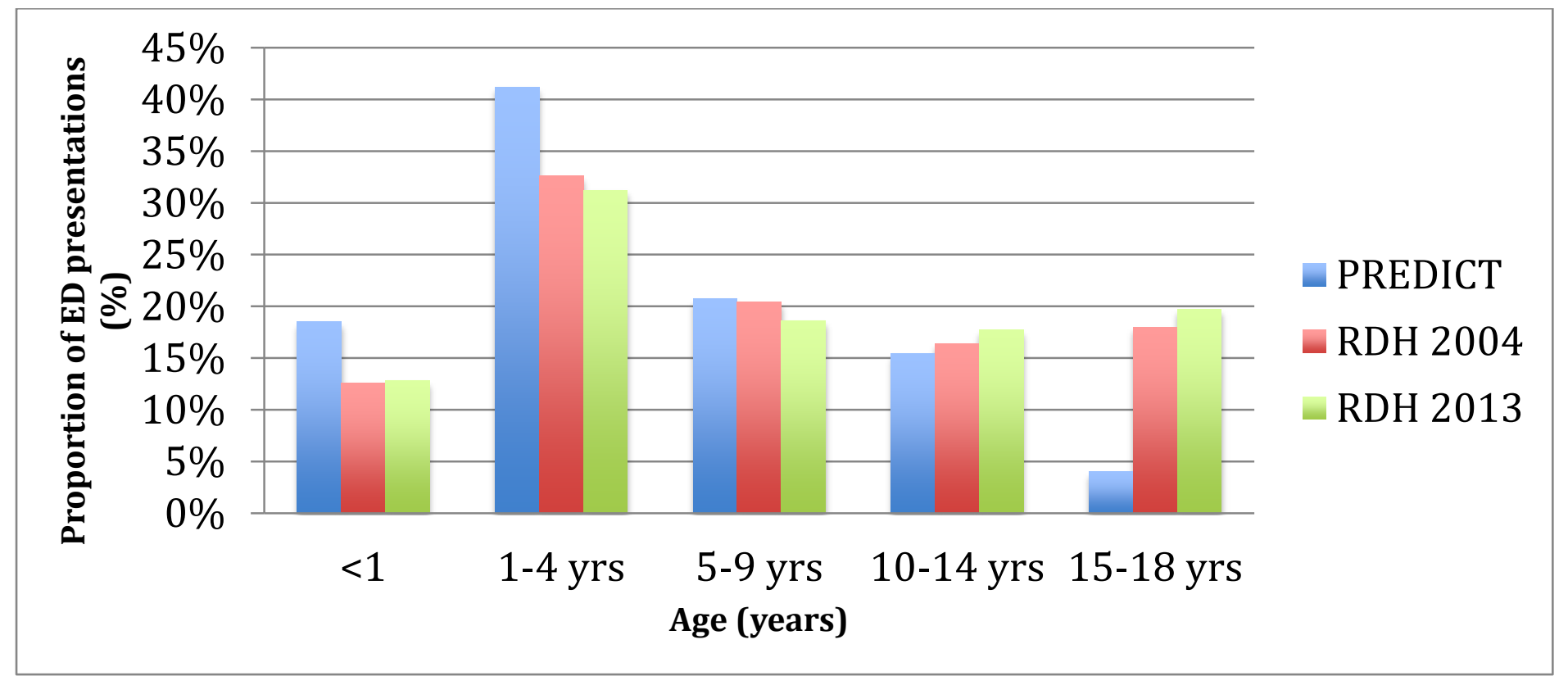

Figure 1. Proportion of ED presentations by age (\%) to PREDICT sites 2004 and RDH Paediatric emergency in 2004 and 2013 


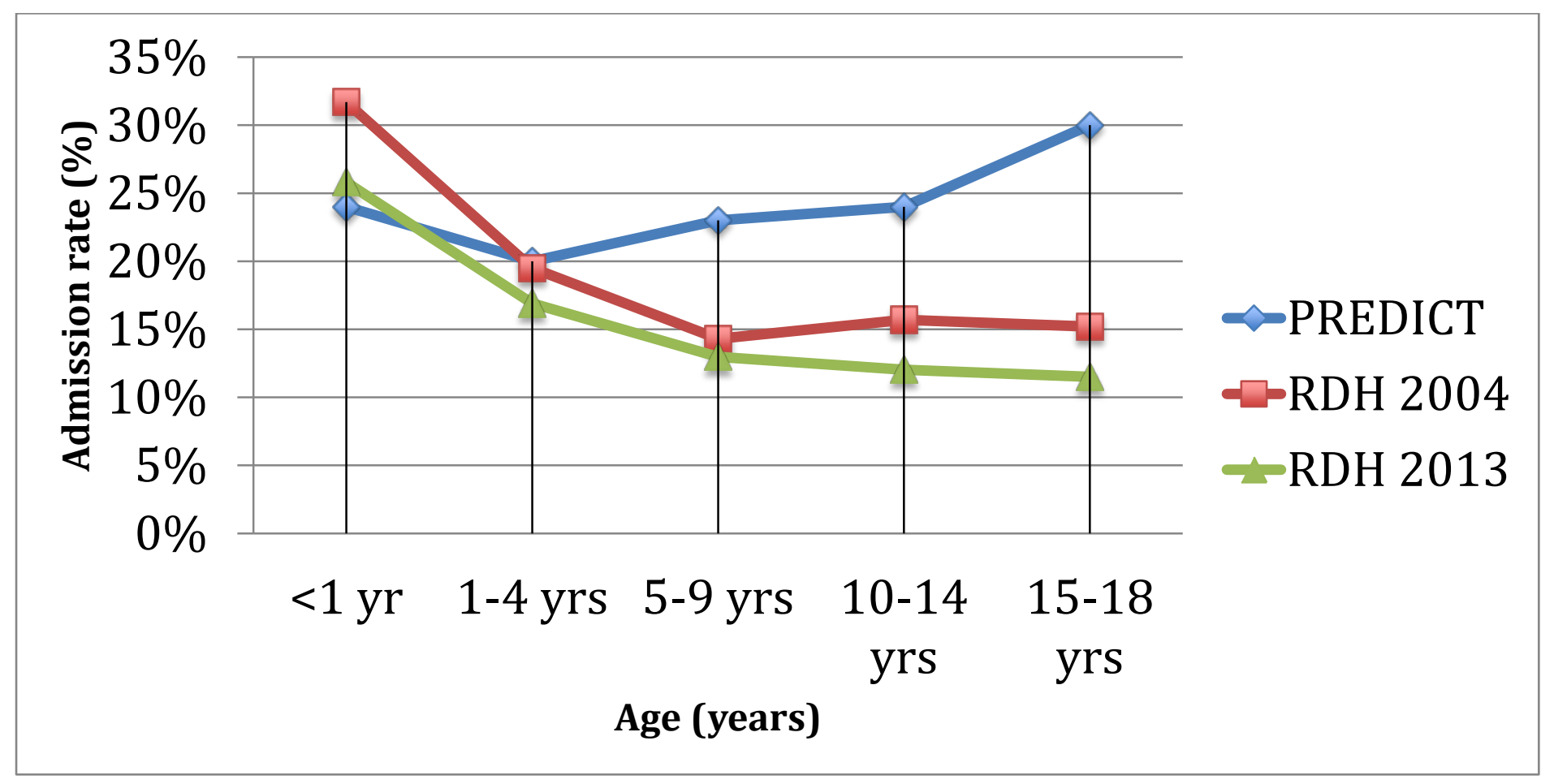

Figure 2. Proportion of admissions by age (\%) to PREDICT sites 2004 and RDH Paediatric emergency in 2004 and 2013 


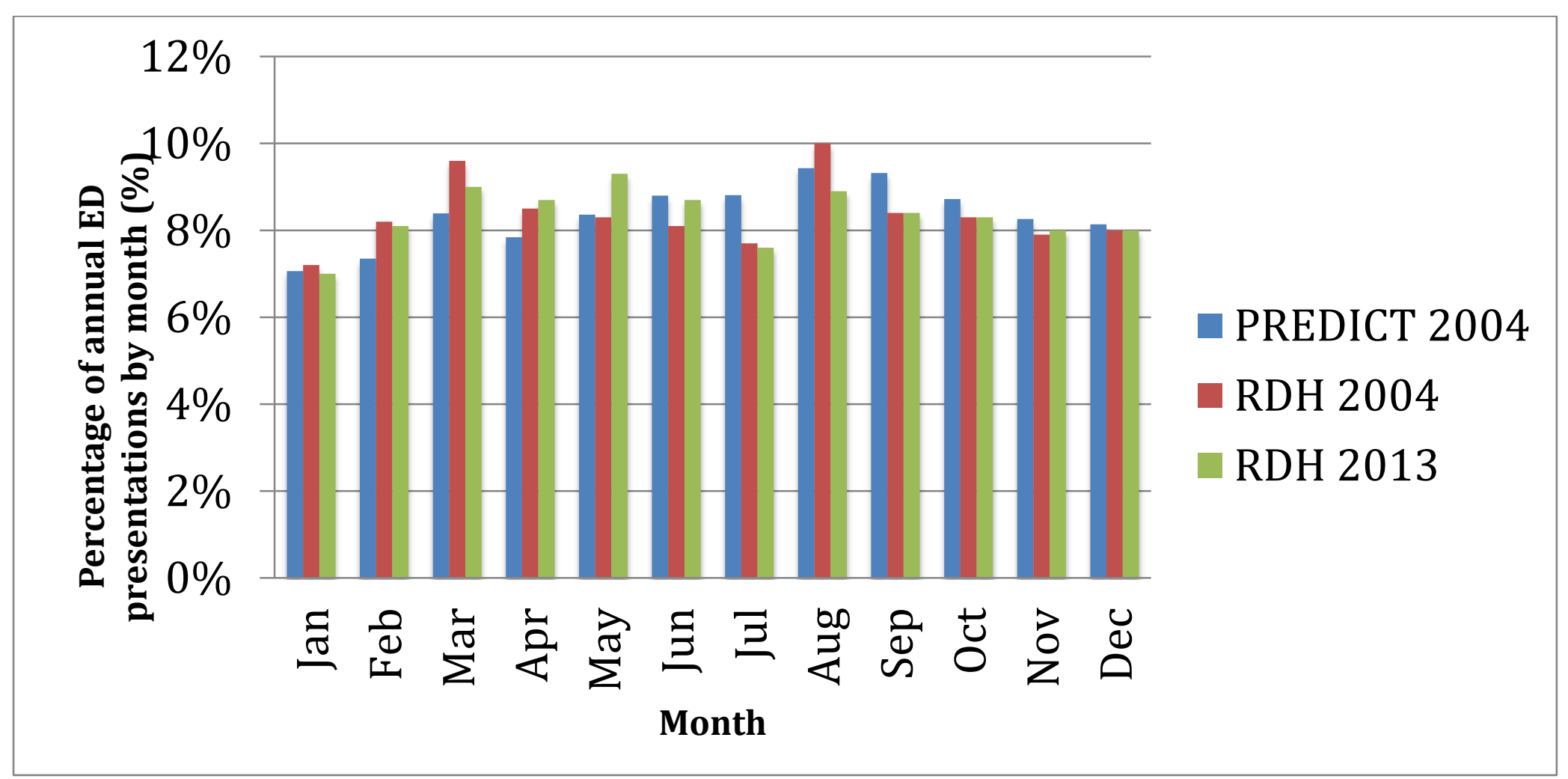

Figure 3. Patterns of presentation per month to RDH Paediatric emergency in 2004 and 2013 
Table 2. Most frequent diagnoses of paediatric ED patients at PREDICT sites 2004 and RDH Paediatric emergency in 2004 and 2013

\begin{tabular}{|c|c|c|c|c|c|c|c|c|c|}
\hline RANK & $\begin{array}{l}\text { PREDICT } 2004 \\
\mathrm{n}=351440\end{array}$ & count & $\%$ & $\begin{array}{l}\text { RDH } 2004 \\
n=12745\end{array}$ & count & $\%$ & $\begin{array}{l}\text { RDH } 2013 \\
n=15378\end{array}$ & count & $\%$ \\
\hline 1 & Gastroenteritis & 19704 & $6.3 \%$ & Gastroenteritis & 884 & $6.9 \%$ & Gastroenteritis & 810 & $5.3 \%$ \\
\hline 2 & Viral IIIness & 15947 & $5.1 \%$ & Viral IIIness & 716 & $5.6 \%$ & Viral IIIness & 748 & 4.9 \\
\hline 3 & URTI & 13956 & $4.4 \%$ & URTI & 554 & $4.3 \%$ & $\begin{array}{l}\text { Abdominal Pain, Non- } \\
\text { specific }\end{array}$ & 707 & $4.6 \%$ \\
\hline 4 & Asthma & 11043 & $3.5 \%$ & $\begin{array}{l}\text { Laceration, face or } \\
\text { Scalp }\end{array}$ & 532 & $4.2 \%$ & $\begin{array}{l}\text { Laceration, face or } \\
\text { Scalp }\end{array}$ & 562 & $3.7 \%$ \\
\hline 5 & Croup & 7369 & $2.3 \%$ & $\begin{array}{l}\text { Abdominal Pain, Non- } \\
\text { specific }\end{array}$ & 470 & $3.7 \%$ & Head Injury & 497 & $3.2 \%$ \\
\hline 6 & Bronchiolitis & 7183 & $2.3 \%$ & Cellulitis & 333 & $2.6 \%$ & URTI & 485 & $3.2 \%$ \\
\hline 7 & Abdominal Pain, Non-specific & 6822 & $2.2 \%$ & $\begin{array}{l}\text { Fractured Forearm } \\
\text { (radius and/or ulna) }\end{array}$ & 311 & $2.4 \%$ & $\begin{array}{l}\text { Fractured Forearm } \\
\text { (radius and/or ulna) }\end{array}$ & 429 & $2.8 \%$ \\
\hline 8 & Laceration, Face or Scalp & 6360 & $2.0 \%$ & Head Injury & 269 & $2.1 \%$ & Cellulitis & 353 & $2.3 \%$ \\
\hline
\end{tabular}

This article is protected by copyright. All rights reserved. 


\begin{tabular}{|c|c|c|c|c|c|c|c|c|c|}
\hline 9 & $\begin{array}{l}\text { Fractured Forearm (radius } \\
\text { and/or ulna) }\end{array}$ & 5186 & $1.7 \%$ & Asthma & 259 & $2.0 \%$ & Bronchiolitis & 327 & $2.1 \%$ \\
\hline 10 & Otitis Media & 4996 & $1.6 \%$ & $\begin{array}{l}\text { Fever without } \\
\text { identifiable source }\end{array}$ & 252 & $2.0 \%$ & $\begin{array}{l}\text { Fever without } \\
\text { identifiable source }\end{array}$ & 294 & $1.9 \%$ \\
\hline
\end{tabular}

This article is protected by copyright. All rights reserved. 
Table 3. Most frequent diagnoses by age of paediatric ED patients at PREDICT, RDH 2004 and 2013.

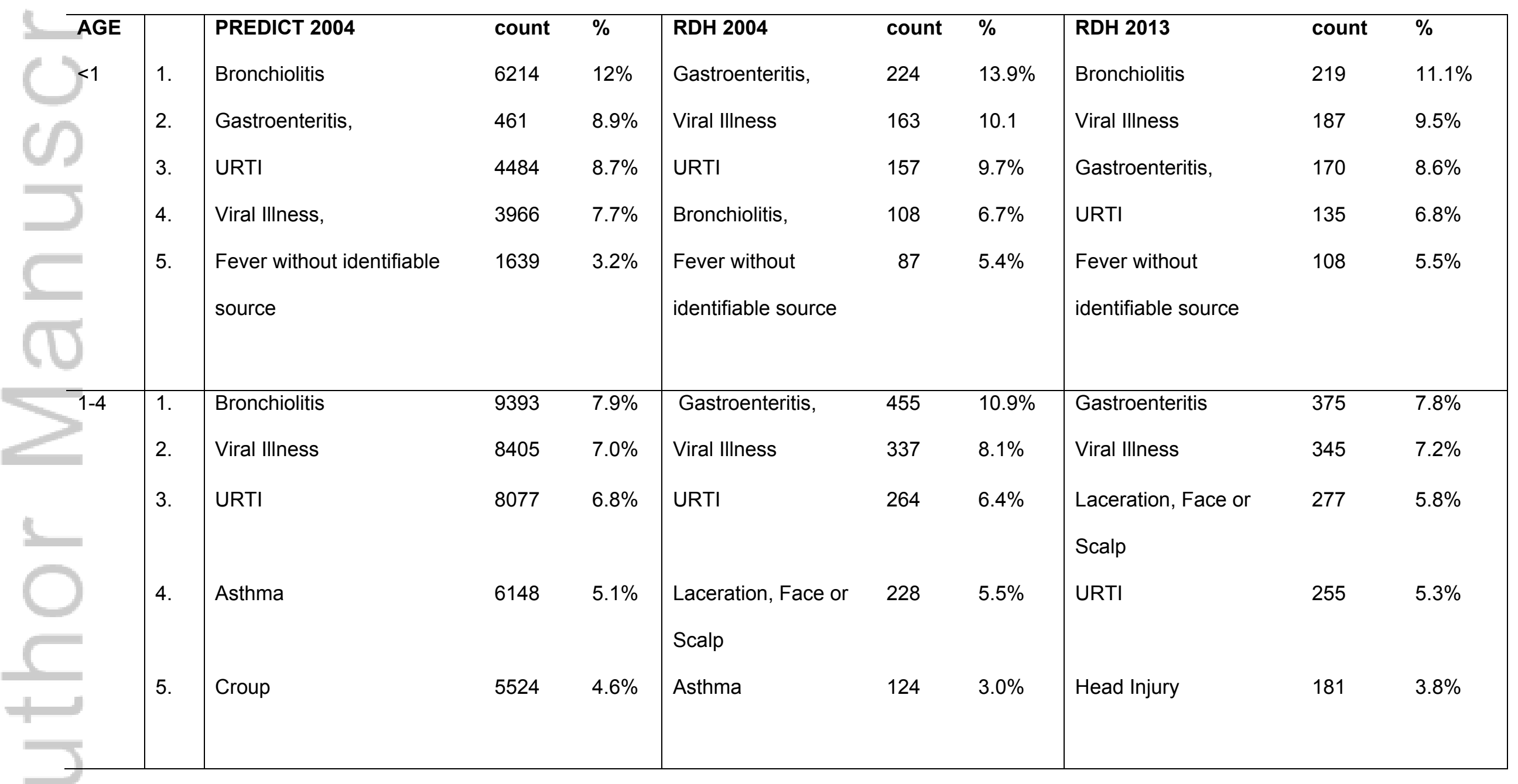

This article is protected by copyright. All rights reserved. 
Table 4. Most frequent diagnoses for Indigenous patients at RDH 2004 and 2013.

\begin{tabular}{|c|c|c|c|c|c|c|}
\hline RANK & RDH 2004 & $\mathbf{n}$ & $\%$ & RDH 2013 & $\mathbf{N}$ & $\%$ \\
\hline 1 & Gastroenteritis, Acute & 310 & $7.8 \%$ & Gastroenteritis, Acute & 208 & $4.6 \%$ \\
\hline 2 & URTI, Acute & 190 & $4.8 \%$ & Cellulitis & 189 & $4.2 \%$ \\
\hline 3 & Viral Illness, Acute & 178 & $4.5 \%$ & Viral Illness, Acute & 168 & $3.7 \%$ \\
\hline 4 & Cellulitis & 173 & $4.3 \%$ & Abdominal Pain, Non-specific & 157 & $3.5 \%$ \\
\hline 5 & Laceration, Face or Scalp & 126 & $3.2 \%$ & Bronchiolitis, Acute & 147 & $3.2 \%$ \\
\hline 6 & Abdominal Pain, Non-specific & 108 & $2.7 \%$ & URTI, Acute & 137 & $3.0 \%$ \\
\hline 7 & Bronchiolitis, Acute & 103 & $2.6 \%$ & Laceration, Face or Scalp & 130 & $2.9 \%$ \\
\hline 8 & Pneumonia, Acute & 96 & $2.4 \%$ & Head Injury & 120 & $2.6 \%$ \\
\hline 9 & Asthma, Acute & 80 & $2.0 \%$ & $\begin{array}{l}\text { Fractured Forearm (radius and/or } \\
\text { ulna) }\end{array}$ & 116 & $2.6 \%$ \\
\hline 10 & Fever without identifiable source & 80 & $2.0 \%$ & Fever without identifiable source & 84 & $1.9 \%$ \\
\hline
\end{tabular}

This article is protected by copyright. All rights reserved. 


\section{University Library}

\section{- M M N E R VA A gateway to Melbourne's research publications}

Minerva Access is the Institutional Repository of The University of Melbourne

Author/s:

Buntsma, D;Lithgow, A;O'Neill, E;Palmer, D;Morris, P;Acworth, J;Babl, FE

Title:

Patterns of paediatric emergency presentations to a tertiary referral centre in the Northern Territory

Date:

2017-12-01

Citation:

Buntsma, D., Lithgow, A., O'Neill, E., Palmer, D., Morris, P., Acworth, J. \& Babl, F. E. (2017). Patterns of paediatric emergency presentations to a tertiary referral centre in the Northern Territory. EMERGENCY MEDICINE AUSTRALASIA, 29 (6), pp.678-685. https:// doi.org/10.1111/1742-6723.12853.

Persistent Link:

http://hdl.handle.net/11343/293833 